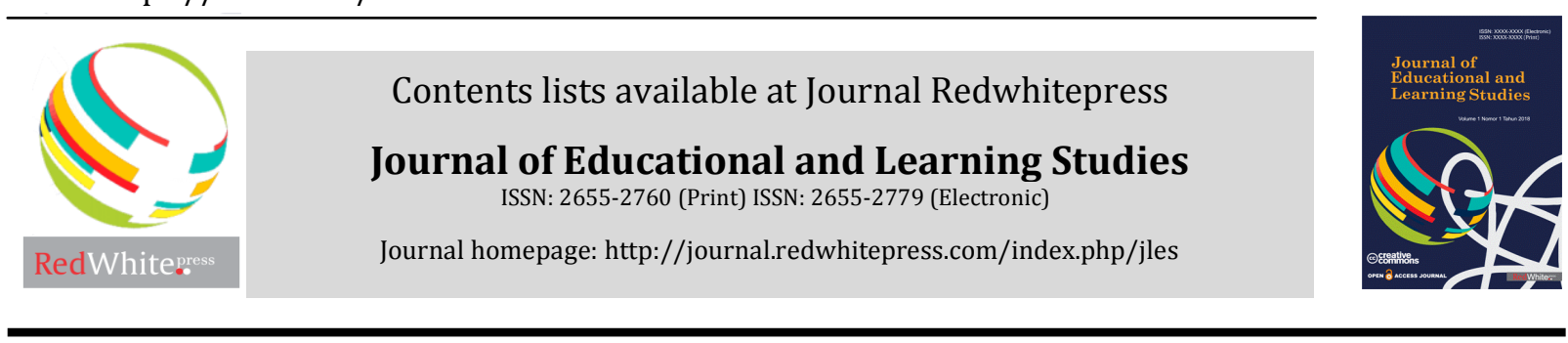

\title{
Integrated thematic learning through contextual learning to improve performance of students with mild intellectual disability
}

\author{
Kasiyati $^{1}$, Zulmiyetri ${ }^{2}$ \\ ${ }^{12}$ Universitas Negeri Padang
}

\section{Article Info}

\section{Article history:}

Received Nov $24^{\text {th }}, 2018$

Revised Nov $27^{\text {th }}, 2018$

Accepted Dec $14^{\text {th }}, 2018$

\section{Keyword:}

Contextual Learning

Integrated Thematic Instructional

Student with Mild Intellectual

Disability

Special Education

\begin{abstract}
This study aims to determine the effect of integrated thematic instructional, through contextual learning model, for improving performance of students with mild intellectual disability. This research uses classroom action research (Action Research), included collaboration with classroom teachers. The subjects of this research are four students with mild intellectual disability in grade VIII. This study uses a cycle, in each cycle consists of planning, action, observation and reflection. Data collected through observation, and tests. Data analysis using qualitative and quantitative analysis. The results showed that, integrated thematic instructional, through contextual learning model, has changed performance of the students from cycle I to cycle II. The result of cycle I showed that the performance of the four students are $\mathrm{R}=48 \%$, $\mathrm{T}$ $=54 \%, \mathrm{~K}=63 \%$ and $\mathrm{S}=59 \%$. In cycle II, the performance of students increasing, $\mathrm{R}=69 \%, \mathrm{~T}=75 \%, \mathrm{~K}=85 \%$, and $\mathrm{S}=81 \%$. It could be concluded that integrated thematic instructional, through contextual learning model, effective for improving performance of students with mild intellectual disability.
\end{abstract}

(C) 2018 The Authors. Published by Redwhitepress.

This is an open access article under the CC BY-NC-SA license (https://creativecommons.org/licenses/by-nc-sa/4.0/

\section{Corresponding Author:}

Kasiyati,

Universitas Negeri Padang

Email: kasiyati@fip.unp.ac.id

\section{Introduction}

Education is very important in human life. Today, according to the understanding of various things, standardization and professionalism in education changes in every components of education system. In curriculum implementation, teachers are required to always learn and get new information about learning and improving the quality of education in general. The quality of education can be enhanced by changing the curriculum and increasing the quality of learning. Improving the quality of education, the government has implemented a new curriculum namely curriculum 2013 in all grades of school education with purpose to improve the quality of learning so that the students' potential more optimal developed.

Instructional in special school based on the curriculum 2013 by using thematic integrated. The Ministry of Education and Culture(2014:16) stated that "thematic integrated learning has afunction to provide convenience for students in order to understand and explore the concept of material incorporated in the theme as well as can add to motivated students to learn more, because the course is real course(contextual) and meaningful for students". Hermawan (2009:5-6) stated that the characteristics of 
the thematic integrated learning are 1) student-centered,2) thematic learning can provide directly experience for students, 3) the separated subject is not clear, 4) presents the concept of a various lessons in learning process, 5) flexible, 6) the results of learning can be developed according to the students' interests.

Preliminary research found that school using thematic integrated learning through scientific approach but learning still emphasize to the subjects and teacher dominating the learning. Therefore, learning is not as expected, students do not play a role in class so that potential students could not developed. In addition, teachers still being the center of learning, that means the learning is not using student-centered approach.

Learning will be more effective if students are actively involved and students learn about real problems in daily living. Confronts students with the real problems, then involving students in problem solving will make the learning process more real and will be more effective because learning process according to the thinking level of students which for primary school level, students thinking in concrete operational. For effective learning, teachers required to solve the real learning problem and implemented the learning process according to procedure. Realize the learning by discuss about real problem in daily living means that teacher should be able to solve and carry out the learning through contextual learning.

Based on the problems above, this study aims to determine the effects of contextual learning for improving the learning process. Gafur (2009:1) stated that contextual learning (CTL) is learning concept that helps teachers linking between the material taught to students 'real situations and encourage students to make connections between the knowledge and child's life plan as family member and community. Measures of contextual learning, according to Sugianto (2009:17) are1) learning introduction, 2) delivering learning materials,3) appearance of the students, 4) giving feedback, and 5) follow-up activities. By this concept, the learning outcomes expected to be more meaningful for the students. The learning process will naturally delivered to the students.

\section{Method}

This research used classroom action research (Action Research) method. Arikunto (2006:104) said that the process of classroom action research is the recycling process that begins with research planning, action implementing, observing and evaluating the process and results of the actions as well as performing reflection until the improvement could be achieved. This study used qualitative and quantitative approaches. This research was conducted by two cycles process since 2016. The subject of rhis study are the teacher and four students with mild intellectual disability, grade V in SLB Khansa, Padang. Data was collected by observation used assessment instruments consist of observation sheet of teacher activity and student activity. Data result was calculated using formula that proposed by The Ministry of Education and Culture (2014:147),

$$
\text { value }=\frac{\text { total score }}{\max \text { score }} \times 100 \%
$$

The cumulative value that used according to The Ministry of Education and Culture (2014:147) as follows:

Table 1. The cumulative value

\begin{tabular}{cc}
\hline Ratings & Value \\
\hline Very good & $90<\mathrm{AB} \leq 100$ \\
Good & $80<\mathrm{B} \leq 89$ \\
Fair & $60<\mathrm{C} \leq 79$ \\
Poor & $\leq 60$ \\
\hline
\end{tabular}

\section{Results and Discussion}

\section{Result}

Based on observation result, this research found that: Performance of students with mild intellectual disability could be improved by thematic integrated learning process through contextual learning model. Observations data results of teacher activities used to examine the development of learning that occurred during the learning. The observation sheet was used to recognize the thematic integrated learning process through contextual learning model. 
In the first cycle, thematic integrated learning process through contextual learning model was not maximum implemented. This happened because of there are several indicators from the observation that not completed well. The overview of the observation results of teaching and learning activities in cycle I, can be seen as follows:

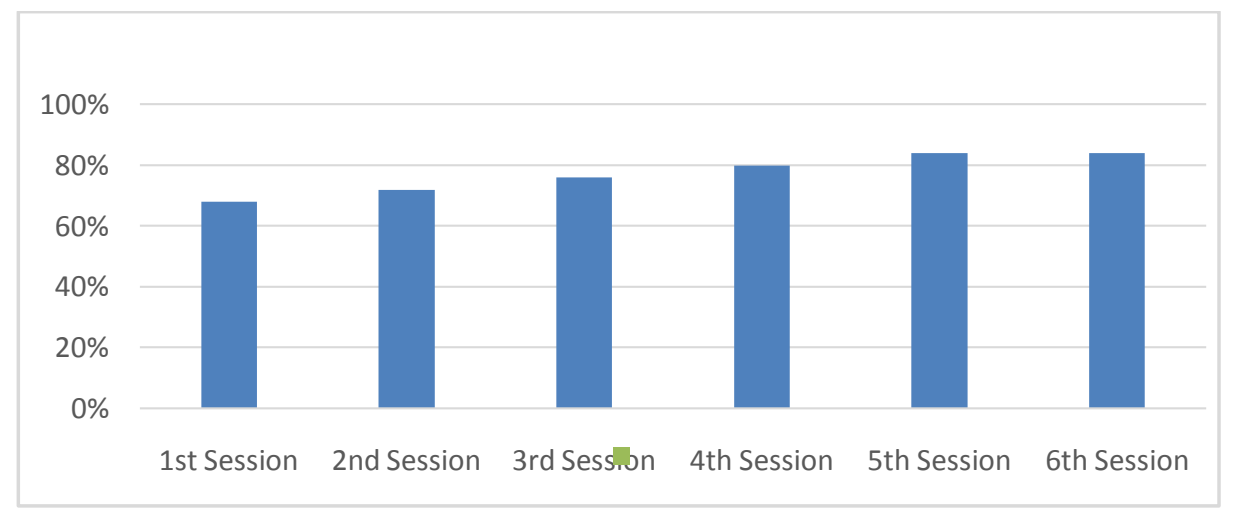

Figure 1. Teacher observation cycle I

Furthermore, the overview of observation teachers activities in cycle II can be seen as follows:

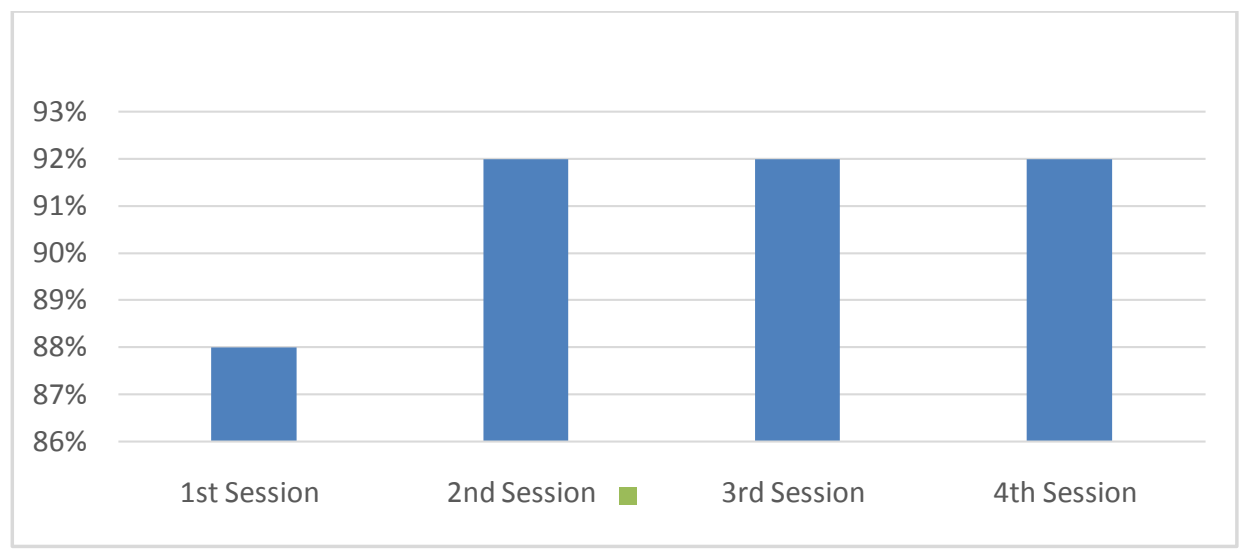

Figure 2. Teacher observation cycle II

During the teaching and learning activities, students activities instruments was used to examine the process of thematic integrated learning through contextual learning model. These instruments consist of three aspects such as attitude, knowledge, and skills.

In cycle I, the students activity in thematic integrated learning not running as expected. it can be seen from indicators that has not been reached yet. The students was not able to find the relation between alternative energy lesson and daily living, but the students is able to ask when they don't understand the lesson.

Furthermore, in cycle II, the activity of students in thematic integrated learning implementation has been complete all of the instrument indicators. In the cycle II, students are able to find the meaning of alternative energy coconut and relate it to daily living. Students also begin to working in group and confidence if teacher ask them to come forward in class. Although there are some indicators which have not run with maximum, the students activity in thematic integrated learning process has been performing well. The increasing aspects performance of students with mild intellectual disability in thematic integrated learning through contextual learning model, could be seen in Figure 3: 


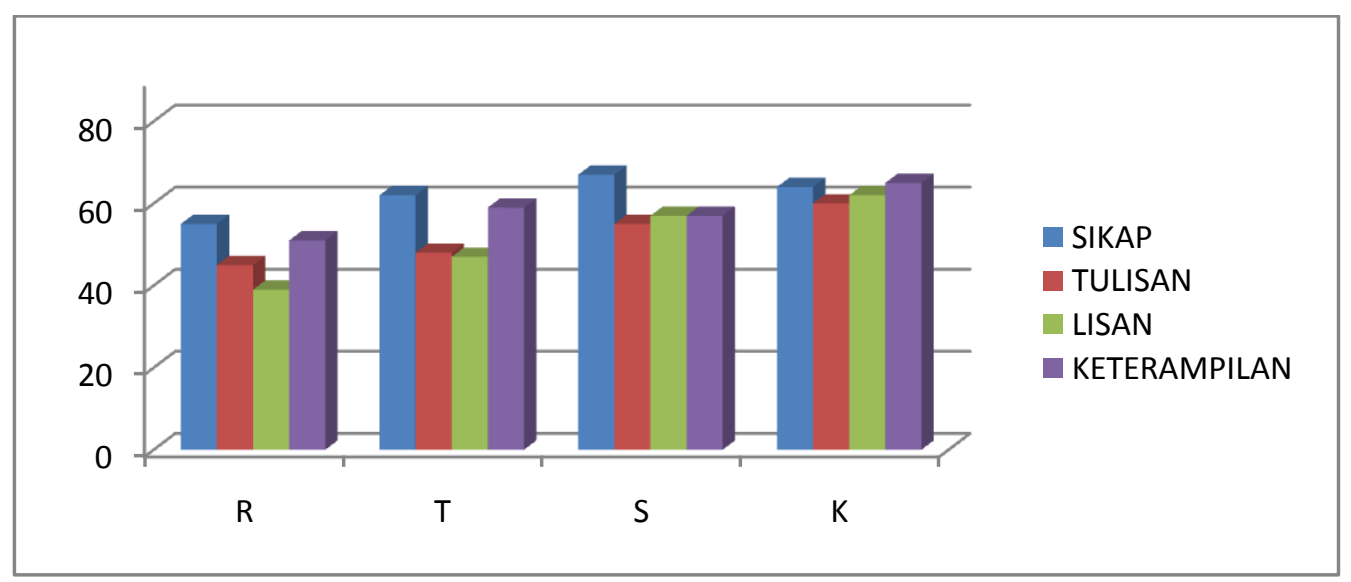

Figure 3. The score of students' performance in thematic integrated learning through contextual learning model (cycle I).

Based on Figure 3, it can be seen that at cycle I, R obtained attitude mean score $=55 \%$, assessment of knowledge by writing $=45 \%$ and assessment of knowledge byoral $39 \%$, and skills score $=51 \%$. $\mathrm{T}$ obtained attitude mean score $=62 \%$, assessment of knowledge by writing $=48 \%$ and assessment of knowledge byoral $47 \%$, and skills score $=59 \%$. Sobtained attitude mean score $=67 \%$, assessment of knowledge by writing $=55 \%$ and assessment of knowledge byoral $57 \%$, and skills score $=57 \%$. Kobtained attitude mean score $=64 \%$, assessment of knowledge by writing $=60 \%$ and assessment of knowledge byoral $62 \%$, and skills score $=65 \%$. Based on the data, it can be known that students' score increased from the first meeting until the sixth meeting even though the score was not high.Therefore, the teachers and collaborators agree to continued in cycle II.It is intended that after students was treated, the students is able to understand alternative energy sub-theme, particularly coconut as alternative energy.

In cycle II the researcher provided the same learning with the first cycle but researchers focus on the practice of making coconut charcoal and practice questions about coconut as alternative energy. So that performance of the students in thematic learning integrated learning increased. Seen from the test results that depicted as follows:

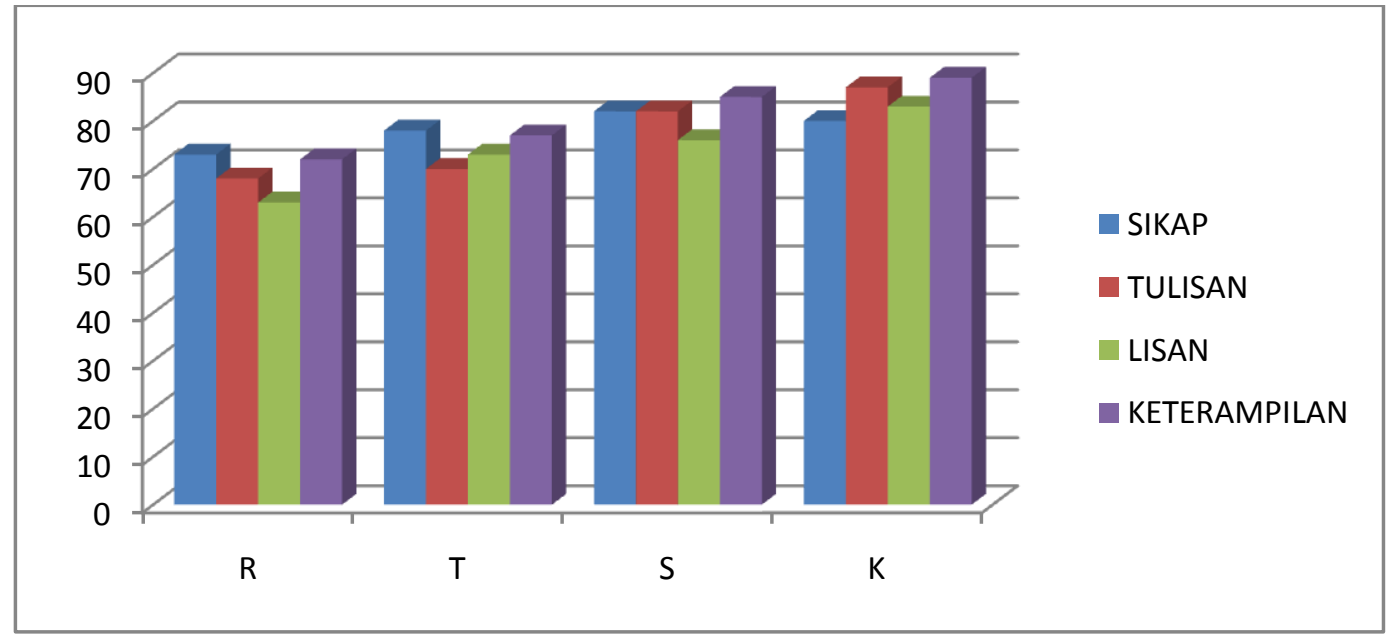

Figure 4. The score of thematic integrated learning through contextual learning Model in cycle II

Data above described that the performance of the students after the given action by contextual learning model has increasing. In cycle II, $\mathrm{R}$ obtained attitude mean score $=73 \%$, assessment of knowledge by writing $=68 \%$ and assessment of knowledge by oral $63 \%$, and skills score $=72 \%$. $\mathrm{T}$ obtained attitude mean score $=78 \%$, assessment of knowledge by writing $=70 \%$ and assessment of knowledge by oral $73 \%$, and skills score $=77 \%$. Sustained attitude mean score $=82 \%$, assessment of knowledge by writing $=82 \%$ and assessment of knowledge by oral $76 \%$, and skills score $=85 \%$. Obtained attitude mean score $=80 \%$, assessment of knowledge by writing $=87 \%$ and assessment of knowledge by 
oral $83 \%$, and skills score $=89 \%$.Based on the results, it can be seen that the score of students has significantly increase. Based on data results, the mean of cycle one and two dominated by the students independently. Because of thematic integrated learning through contextual learning model on alternative energy theme could appropriately implemented for students.

\section{Discussion}

Based on the results obtained that implemented thematic integrated learning through contextual learning model for improving performance of students with mild intellectual disability goes well. This can be found from the establishment of good communication between children, teachers and collaborators in discussing the lesson. Kemis \& Ati (2013:84-85) stated that general principles of learning for students with mild intellectual disability is principle of social relations. Teachers present the teaching and learning process by using contextual learning model. Elaine B. Johnson(2007: 64)mentioned that contextual is the concept of learning that help teachers links between the material taught and students' real situations and also encourage students to make connections between knowledge and daily living as a member of family and community.

In the process for improving the learning about alternative energy by thematic integrated through the contextual learning model, researchers associated the lesson that has been learned with daily living activity so that students understand about the lesson. Coconut oil as alternative energy is easily found in daily life and lesson about coconut as alternative energy can be attributed in some subjects. Reading text about the benefits of coconut trees could be introduced in Indonesian Language subject, coconut as an alternative energy are used in daily life could be introduced in sains subject, forms which is in the coconut tree could be introduced in Math and making coconut shell charcoal could be introduced in Art subject. This is relevant with the opinion of Andi (2013: 117), which stated that thematic integrated learning model using a theme to tie some subjects, so that can give meaningful experiences to the students. Thematic integrated learning through contextual learning model are required students to implement the four components consisting of inquiry, observing images, asking, community learning i.e. teamwork or study together, modeling and performing in front of the class. This is relevant with the opinion of the Sukayati (in Andi 2013:140) which mentioned that the purpose of thematic integrated learning is developing skills to find, process, and utilize the information, in addition also developing social skills such as cooperation, tolerance, communication, respect each other opinions and increasing students' interest.

Based on the results of the research, it found that in cycle I, all the items of instrument that has been tested, there are some things that have not been mastered by students. This is relevant with the opinion of Amin (1995:35) which mentioned that one of the characteristics of students with mild intellectual disability is limited in mental functions. Students have a problem about focusing and expressing a memory. Although the achievement of the students has reached the average level, but based on all the assessment, the students still need treatment to improve their performance in cycle II. In cycle II, almost all of the items of instrument have been mastered by the students. The students also showed a good attitude and can solve problems by oral and writing as well as the students can practice how to make coconut shell charcoal. The difference between cycle I and cycle II is learning principles for students with mild intellectual disability, habituation principle, should be noted. In cycle II, activity held in four times meeting so that the students is easier to remember the lesson about coconut as alternative energy. Based on those things, students' performance can be increased and obtained good results.

\section{Conclusion}

Based on the discussion, it could be concluded that integrated thematic instructional, through contextual learning model, effective for improving performance of students with mild intellectual disability. It can be found in the components of contextual learning model which consists of inquiry (finding), asking, community learning and modeling. In cycle I, the students are not able to find the relation between alternative energy and daily life but the students is able to ask if they don't understand the lesson. In the cycle II, students are able to find the meaning of alternative energy coconut and relate it to daily living. Students also begin to working in group and confidence if teacher ask them to come forward in class. 


\section{References}

Abdul Majid. (2014). Pembelajaran Tematik Terpadu. Bandung : PT Remaja Rosdakarya. Amin, Moh. (1995). Ortopedagogik Anak Tunagrahita. Bandung: Depdikbud.

Arikunto,Suharsimi (2006). Penelitian Tindakan Kelas.Jakarta: PT. BumiAksara.

Asrori, Muhammad. (2007). PenelitianTindakanKelas. Bandung: CV WacanaPrima.

Johnson, B. Elaine. (2002).Contextual Teaching \& Learning. Bandung: Penerbit Kaifa.

Kemis. (2013). Pendidikan Anak Berkebutuhan Khusus Tunagrahita. Bandung: Luxima Metro Media.

Mulyasa. (2012). PraktikPenelitianTindakanKelas. Bandung :RosdaKarya 